\title{
Giovanni Cipriani
}

\section{Republican Ideology and Humanistic Tradition: the Florentine Example}

Since the Middle Ages the imperial political pattern, which was alive in the Holy Roman Empire, did not only represent a political entity but a living ideal frame of reference to which the Biblical and Roman traditions seemed unfailingly to lead. Concrete more than ideal motivations lay at the core of the republican communal reality. As this reality became established in a large part of the Italian peninsula, however, the development of an autonomous political ideology became a heartfelt and straightforward necessity.

The Roman world contained elements of both republican and imperial ideology. As scholarly investigations of the ancient past spread in Italy during the $\mathrm{XV}^{\text {th }}$ century, investigation of the oldest political traditions increased as well. Going backwards in time, probing the roots of antiquity, historians rebuilt the Italian political geography and unearthed a twofold Etruscan political model, side by side with that of republican and imperial Rome.

In Tuscany above all the discovery of an autochthonous past could be used to bolster up the form of the contemporary government, and some humanists actually worked in this direction. At the beginning of the XIV th century Giovanni Villani had already emphasized the "potenza e signoria ch'avea la provincia di Toscana innanzi che Roma avesse stato" . He made clear that "le sue confine, dette colonne, erano infino alla città d'Adria in Romagna, in sul golfo del mare di Vinegia ... e nelle parti di Lombardia ... infino di là dal fiume di Po e del Tesino"2; it was Coluccio Salutati, however, who claimed for Florence and Tuscany the Etruscan and the Roman republican heritage.

From this viewpoint the Otto Santi $w^{3}{ }^{3}$ and, above all, the fight against Giangaleazzo Visconti ${ }^{4}$ represented moments of great creativeness. The purpose of the Duke of Milan was clear. Determined to extend his hegemony throughout central and

1 Giovanni Villani, Cronica, in: Croniche di Giovanni, Matteo e Filippo Villani secondo le migliori stampe e corredate di note filologiche e storiche (Trieste, Milano 1857) Vol. I, book I, chap. XLIV, 24.

2 Ibid.

${ }^{3}$ See $R$. C. Trexler, Who were the Eight Saints?, in: Renaissance News XVI (1963) 89-94.

4 See D. M. Bueno de Mesquita, Giangaleazzo Visconti Duke of Milan 1351-1402 (Cambridge 1941). Interesting pages in Giovanni di Pagolo Morelli, Ricordi, a cura di V. Branca (Firenze 1956). 
northern Italy, Giangaleazzo took possession of Pisa, Siena, Perugia and Assisi in the period from 1399 to 1400 , thus surrounding the Florentine State.

Locked in a deadly embrace, Florence summoned up every resource for the struggle against the powerful enemy. At the military level Florence kindled the ambitions of the young emperor Rupert of Wittelsbach and invited him to come down to Lombardy with an army. In the meantime a hard ideological struggle was carried out between Antonio Loschi on the one hand and Coluccio Salutati and Cino Rinuccini on the other.

Humanism was already intensely experienced as a constitutive element, both of individual learning and of a collective culture which was represented by autochthonous traditions that history and philology filled with symbolic meanings. Florence and Milan, engaged in a struggle without quarter, made clear the political content of an intellectual tradition which had so far been connected only with the rebirth of antiquity.

Already in 1397 , shortly after the outbreak of the war, Antonio Loschi, chancellor in the pay of Giangaleazzo Visconti, did, in fact, send the Florentines a violent Invectiva ${ }^{5}$ whereby he charged them as the real aggressors in the fight against Milan and, above all, as having falsely declared their Latin heritage. Cino Rinuccini and Coluccio Salutati after him, rose indignantly and powerfully claimed the moral and cultural superiority of their city. "Ancora spargi, o sciocchissimo, molte parole vanitose", Rinuccini wrote in his Responsiva; even more explicit was Coluccio Salutati in his famous Invectiva in Antonium Luschum Vicentinum: "Pudeat te spurcissimorum spurcissime stercus et egeries Lombardorum vel potius Longobardorum, Florentinos, verum et unicum Italiae decus, faecem Italiae nominare. ${ }^{\text {"7 }}$

Florence was not only a town, she was the very symbol of the struggle against tyranny; with extreme boldness Salutati did not hesitate to call the Tuscan town indestructible because of the strength and independence of her inhabitants: "Talis est, ni fallor, populus Florentinus quem difficile sit ad unum penitus interire. Capta quidem, quod Deus avertat, dirutaque Florentia, tot sunt extra Florentiam Florentini quod viris et opibus novam possunt, alteris vel refectis moenibus, Florentiam excitare. ${ }^{\text {“8 }}$

The Etruscans alone, who were conceived of as the ancient Tuscans, had been able to withstand the Latins and did not fear them militarily. More significantly Etruscan power was demonstrated by the extent of their rule, so ample as to reach the Adriatic, the name of which was thought to derive "ab Adria, Tuscorum colonia"'. Florence

\footnotetext{
${ }^{5}$ See Hans Baron, Humanistic and Political Literature in Florence and Venice at the Beginning of the Quattrocento (Cambridge/Mass. 1955) 38-47.

- C. Rinuccini, Risponsiva alla invettiva di Messer Antonio Lusco, in: C. Salutati, Invectiva Lini Colucii Salutati Reipublicae Florentinae a secretis in Antonium Luschum Vicentinum de eadem republica male sentientem (Firenze 1826) 206. See Hans Baron, La crisi del primo Rinascimento italiano. Umanesimo civile e libertà repubblicana in un'età di classicismo e di tirannide, trad. ital. (Firenze 1970) 98; Baron, Humanistic and Political Literature, 47-50.

7 Salutati, Invectiva, 126.

B Ibid., 7-8.

9 Ibid., 168.
} 
herself had originated from the Etruscan "civitas Faesulana" 10 and received her earliest urban structure from the republican leader Sulla and from his soldiers.

The Etruscan and the Roman republican traditions were called upon to supply the key ideological element supporting the viewpoint of the Florentine humanists; in spite of this powerful effort, however, the outcome of the Milanese war was doubtful. The superiority of the ducal army was obvious; after the defeat of Giovanni Bentivoglio at Casalecchio (26 June 1402) and the conquest of Bologna, Giangaleazzo Visconti seemed ready to launch the final attack against Florence.

As Giovanni di Pagolo Morelli in his Ricordi tells us, Florence experienced terrible days of waiting and only the sudden death of Visconti, on 3 September 1403 in Marignano, dissolved the fear. A miracle had happened. "Istando le cose in questi termini Idio e la sua madre Vergine Maria e 'l beato messere Santo Giovanni Batista promissono, acciò che tanto male non seguisse, che il Duca malò di male pestilenziale." ${ }^{11}$ Thus the plague had saved Florence and restored that balance of power among the Italian States that had been deeply altered only a few years before.

The Tuscan town emerged from the fight renewed. Firm in her republican institutions, proud to be the symbol of the struggle against tyranny, she reached an harmonic cohesion in her politics both at home and abroad, where she was now endeavouring to win control of Pisa and her surrounding territory. Florence felt herself "urbs eiusmodi ... ut nichil neque luculentius neque splendidius in toto orbe terrarum inveniri possit"12. Leonardo Bruni expressed the feelings of many Florentines in his Laudatio Florentinae urbis, composed either in the summer 1403 or in that of the following year ${ }^{13}$.

Bruni's work, patterned after the Panatbenaicus by Elio Aristide ${ }^{14}$, contained only a far echo of the struggle against the Visconti but the ideal image of Florence as a free city-state, heir to that republican Rome where liberty had ruled for so many centuries, held a most prominent role in it. The Romans had been the ones who founded the Tuscan town when "nondum Cesares, Antonii, Tiberii, Nerones, pestes atque exitia reipublicae, libertatem sustulerant sed vigebat sancta et inconcussa libertas quae tamen, non multo post hanc coloniam deductam, a sceleratissimis latronibus sublata est"15, and for this reason "iure quodam hereditario ceu paternarum rerum possessio" 16 , to the Florentines belonged "dominium orbis terrarum"17.

${ }^{10}$ Ibid., 25.

${ }^{11}$ Morelli, Ricordi, 399. See Gene Brucker, The Civic World of Early Modern Renaissance Florence (Princeton 1977) $187 \mathrm{ff}$.

${ }^{12}$ Leonardo Bruni, Panegirico della città di Firenze, testo italiano a fronte di frate Lazaro da Padova, Presentazione di G. De Toffol (Firenze 1974) 11. Critical edition in Hans Baron, From Petrarca to Leonardo Bruni. Studies in Humanistic and Political Literature (Chicago 1968) 217-263.

${ }^{13}$ See Baron, La crisi, 231-243 and in particular 245; Baron, Humanistic and Political Literature, 69-107.

14 See Baron, La crisi, 210; Giovanni Cipriani, Il mito etrusco nel rinascimento fiorentino (Firenze 1980) 6 .

is Bruni, Panegirico, 46.

${ }^{16}$ Ibid., 44.

17 Ibid. 
The consciousness of such an outstanding position, with the political and ideological implications attendant upon it, thoroughly legitimised the investigation into the past of the Florentine Republic. Doubtless Leonardo Bruni was the best spokesman of civic republicanism and, as learned humanist, he dug in depth. He had read Livy and was well informed about the war of the Romans against the Etruscans; in Bruni's work therefore, the character of the Florentines, who had proved themselves proud enemies of tyranny, acquired more specific outlines since they equally emerged as heirs to the free Roman citizens and the ancient Etruscans.

Bruni was the first to discover the meaning of Etruscan urban civilization and his Historiarum Florentini Populi libri XII ${ }^{18}$ make his discovery clear. In his account the history of Florence had to be rewritten: "Florentiam urbem Romani condidere a Lucio Sylla Fesulas deducti. Fuerunt autem hi Syllani milites quibus ob egregiam cum in caeteris tum in civili bello navatam operam pars Fesulani agri est attributa et Fesulae una cum veteribus incolis sedes traditae. " 19 If it was a fact that Florence, cradle of republican liberty, originated from Sulla's soldiers, it was also a fact that the Etruscans were present in that land. Everybody knew that: "Ante Romanum quidem imperium longe maximas totius Italiae opes maximamque potentiam ac prae caeteris, vel bello vel pace, inclitum nomen Etruscorum fuisse, inter omnes antiquissimos rerum scriptores haud ambigue constat. ${ }^{20}$

The Etruscan political system was carefully highlighted and if "ab initio rex unus gubernabat" 21 , later "ut regia potestas gravior illis visa, ex singulis populis singulos Lucumones, (sic enim magistratum vocitabant qui communi consilio totam regeret gentem) creare coeperunt"22. The Etruscans, the ancient Tuscans, possessed free citystates at first, ruled by "Lucumones" whose power was not rigid and absolute, as the words "communi consilio" clearly pointed out. Statements of this sort provided the evidence to support the humanists' contention that Tuscany had been the cradle of republican liberty. For this very reason the Florentines were "tyrannorum valde ... inimici"23. For this they loved liberty "maxime omnium"24.

The Roman heritage, as Bruni argues, legitimized the Florentine wars as the recovery of something lost. So much that "ut omnia bella quae a Populo Florentino geruntur iustissima sint nec possit hic populus in gerendis bellis iustitia carere cum omnia bella pro suarum rerum, vel defensione vel recuperatione, gerat necesse est, quae duo

${ }^{18}$ See E. Santini, Leonardo Bruni Aretino e i suoi Historiarum Florentini Populi libri XII, in: Annali della R. Scuola Normale Superiore di Pisa XXII (1910) 1-174; E. Santini, La fortuna della Storia Fiorentina di Leonardo Bruni nel Rinascimento, in: Studi Storici XX (1891) 177-195; Baron, La crisi, passim; D. J. Wilcox, The Development of Florentine Humanist Historiography in the Fifteenth Century (Cambridge/Mass. 1969) 32-129.

19 Leonardo Bruni, Leonardi Aretini Historiarum Florentini Populi libri XII, a cura di E. Santini, in: Rerum Italicarum Scriptores. Raccolta degli storici italiani dal Cinquecento al Millecinquecento ordinata da $L . A$. Muratori, Nuova edizione riveduta, ampliata e corretta con la direzione di G. Carducci e V. Fiorini, tomo XIX, parte III (Città di Castello 1914-1926) book I, 5.

${ }^{20}$ Ibid., 7.

${ }^{21}$ Ibid.

22 Ibid., 7-8.

${ }^{23}$ Bruni, Panegirico, 46.

${ }^{24}$ Ibid. 
bellorum genera omnes leges omniaque iura permittunt" 25 , now, however, a new heritage and a new source of legitimation were added. Indeed the Etruscans, the ancient Tuscans, had been in many ways mentors of the Romans: "Constat autem Romanos praetextam et trabeas, phalerasque et anulos, togas quoque pictas et palmatas, tunicas, currus insuper aureos triumpho decoros, fasces denique et lictores et tubas et sellam curulem ac caetera omnia regum magistratuumque insignia ab Etruscis sumpsisse"; furthermore "Nec imperii tantum insignia, caeterumque augustiorem habitum sumpserunt ab Etruscis verum etiam literas disciplinamque ... Nam caeremonias quidem ac religionem et cultum Deorum, qua in arte Etrusci prae caeteris gentibus excelluisse traduntur, Romani sic ab illis susceperunt ut tamen priores partes relictas penes auctores ipsos faterentur. Simulatque gravius quidquam reipublicae imminebat, in quo Deum numina placandum censerent, vates et aruspices ex Etruria vocabantur."26

Above all, in their cult of the divine the ancient Tuscans had been sublime; if it held true that the Latins learned from them their own rites and ceremonies, it also held true that this ancient religious tradition was still living in Florence.

Bruni meant to emphasize the fact that between the Etruscans and the Romans there had never been incurable contrasts and he also believed that the Etruscan forces, when they were weakening, had been absorbed into the Roman forces as their worthy heirs, because, "cum Romanis vero non odio neque acerbitate unquam pugnatum, plus etiam amicitiae quam belli interdum fuit" ${ }^{27}$. After many centuries the same process repeated itself in Florence. The Roman forces, now also weakening, together with their previous Etruscan heritage, entered the Tuscan town. Thus Florence, making old splendour, come alive again, actually became the spiritual fatherland of all Italians.

The term "Etruscan" soon became a synonym for noble and generous: "Quid igitur, aut pace aut bello, magis inclitum esse potest quam Etruscum nomen si antiquitatem et vetustatem gentis gloriam inspicias?" 28, wrote Leonardo Bruni to Francesco Gonzaga on 26 May 1418, as he celebrated, on the grounds of Plinius Naturalis historia ${ }^{29}$, the Etruscan origins of Mantova and while venting his pride for his share in the ancient glory of that city.

Etruscan and Roman at the same time, Florence withstood with renewed strength Filippo Maria Visconti's attack. In May 1427, the death of Nanni degli Strozzi, the only military commander in the Florentine army who was not a mercenary, provided a new opportunity for Bruni's celebration of his adoptive city. "Civitate amplissima atque maxima, lati dominii, summae auctoritatis, Etruscarum quidem civitatum, sine

${ }^{25}$ Ibid., 44.

${ }^{26}$ Bruni, Historiarum, book I, 9.

${ }^{27}$ Ibid.

${ }^{28}$ Leonardo Bruni, Leonardi Bruni Arretini Epistolarum libri VIII ad fidem codicum manuscriptorum suppleti et castigati et plusquam XXXVI epistolis quae in editione quoque Fabriciana deant, locupletati. Recensente Laurentio Mehus Etruscae Academiae Cortonensis socio, qui Leonardi vitam scripsit, Manetti et Poggii orationes praemisit, indices, animadversiones praefationemque adiecit, librumque nonum ac decimum in lucem protulit. Accessere eiusdem epistolac Populi Florentini nomine scriptae nunc primum ex codicibus manuscriptis in lucem editae (Firenze 1741) pars secunda, lib. X, epist. XXV, 229.

29 "Mantua Tuscorum trans Padum sola reliqua." Plin., Nat. Hist., III, 19. 
controversia, omnium principe, Italicarum vero ... neque genere, neque opibus, neque magnitudine cuiquam secunda" ${ }^{30}$; such was the solemn tone of the Oratio in funere Nannis Strozae ${ }^{31}$. The reason of this greatness stood clearly out and belonged to the very origins of the town: "Ad cuius originem civitatis duae nobilissimae ac praestantissimae totius Italiae gentes coierunt, Tusci, veteres Italiae dominatores et Romani, qui terrarum omnium virtute sibi et armis imperium pepererunt. ${ }^{432}$ Nobody could have doubts about the Etruscan excellence. In idealized humanistic fashion the Etruscans embodied the free republican political system thanks to the form of their government and Florence emerged as the main heir of such an old tradition.

The coming to power of Cosimo il Vecchio in 1434 altered these ideals remarkably. Once again Leonardo Bruni provides precious evidence of this change in the political

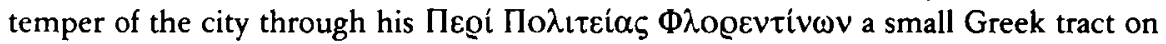
Florentine political institutes written in 1439 in the context of the Council of Florence $^{33}$. However, it is interesting to point out that the connection with the Etruscan republican tradition survived for a long time in Florentine political culture.

In the face of all this Niccolò Machiavelli at the beginning of the XVI ${ }^{\text {th }}$ century realized the positive aspects of the "modo delle leghe come viverono i Toscani ... e come oggi vivono i Svizzeri" ${ }^{34}$ and invited his fellow citizens to keep in mind the Etruscan alternative to the Roman political model: in case "la imitazione de' Romani paresse difficile ... non doverrebbe parere così quella degli antichi Toscani, massime a presenti Toscani. Perché se quelli non poterono ... fare uno imperio simile a quel di Roma, poterono acquistare in Italia quella potenza che quel modo di procedere concesse loro" 35 .

Similarly Piero Vettori spurred the army to the last defence of the Florentine Republic on 5 February 1530, by calling with such words in his Oratione: "Et non è nuova ai Toscani la gloria dell'arme ... Io dico de' più rimoti secoli et che quasi per lunghezza sono in oblivione a molti, ma a noi è vergogna non saper le cose virtuosamente fatte dagl'antichi habitatori di questo nostro paese. Quelli antichi buo' Toscani così come e furono autori della disciplitia delli auguri et in quelle cerimonie mirabilmente lodati, così ancora meritaron gran fama nella disciplina militare, per mezzo della quale in modo ampliarono il loro dominio che quasi tutta Italia obediva alle lor arme." ${ }^{36}$ And he wished "d'havere a rinnovare l'imperio et la gloria di quei bellicosi

${ }^{30}$ Leonardo Bruni, Eloquentissimi viri Leonardi Aretini oratio in funere Nannis Strozae Equitis Florentini, in: E. Baluze, Stephani Baluzii Tutelensis miscellanea novo ordine digesta et non paucis ineditis monumentis opportunisque animadversionibus aucta, opera ac studio, Johannis Dominici Mansi Lucensis (Lucca 1761-1764) tom. IV, 3.

${ }^{31}$ See Baron, La crisi, 411-412, 447-449, 466-471.

${ }^{32}$ Bruni, Oratio, 3.

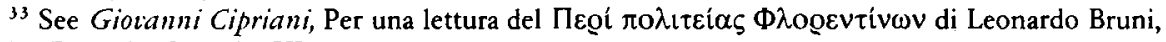
in: Ricerche Storiche XI (1981) 619-624.

${ }^{34}$ Niccolo Machiacelli, Il Principe e Discorsi sopra la prima deca di Tito Livio, con introduzione di G. Procacci e a cura di Sergio Bertelli (Milano 1971) Discorsi, book II, ch. IV, 289.

${ }^{35}$ Machiavelli, Discorsi, book II, ch. IV, 291.

${ }^{36}$ P. Vettori, Oratione di Piero Vettori fatta alla Militare Ordinanza Fiorentina l'anno MDXXX il di (5 Febbraio), in: $R$. von Albertini, Firenze dalla Repubblica al Principato. Storia e coscienza politica, trad. ital. (Torino 1970) Appendice 419. 
Toscani, perché siamo pur nati sotto il medesimo cielo, atto a produrre generosi animi et leggiadri, né s'ha a stimare ch'abbia mutato natura ma che sia più tosto stata cagione del nostro pigro sonno la mala educatione ch'annighittisce et addormenta ogni generoso spirito col nutrirlo in opere abiette et meccanice" ${ }^{37}$.

37 Ibid. 
